\title{
UM ENSAIO SOBRE A MULTIPARENTALIDADE: EXPLORANDO NO ONTEM PEGADAS QUE LEVARÃO AO AMANHÃ
}

\author{
AN ESSAY ON MULTIPLE PARENTHOOD: EXPLORING IN THE PAST \\ THE FOOTPRINTS WHICH WILL TAKE TO THE FUTURE
}

Marcos Catalan*

RESUMO: Depois de revisitar momentos apagados da memória - em parte, pela arrogância contida nas correntes positivistas que se propõe a pensar o direito - e de demonstrar que a multiparentalidade é uma construção cultural que teima em sobreviver à racionalidade eurocêntrica, este estudo tem por escopo aferir se tais entidades familiares - esquecidas pela codificação civil brasileira, embora pulsantes no palco sobre o qual cada existência é vivida - poderão ser reconhecidas e tuteladas pelo Direito pátrio.

PALAVRAS-CHAVE: Família. Multiparentalidade.

ABSTRACT: After pass by moments cleared from the memory and demonstrate that multiple parenthood is a cultural construct, this study intents to prove if such entities - forgotten by the Brazilian civil code - may be recognized and safeguarded by the Brazilian civil law.

KEYWORDS: Family. Multiple parenthood.

* Doutor summa cum laude em Direito pela Universidade de São Paulo. Mestre em Direito pela Universidade Estadual de Londrina. Professor nos cursos de Direito da Unisinos, da Unilasalle e em cursos de Especialização pelo Brasil. Parecerista e consultor jurídico. E-mail: marcoscatalan@uol.com.br 


\section{ALgUMAS VERDADES NÃO FORAM CONTADAS PELOS Códigos DA MODERNIDADE}

As dicotomias impregnadas ao pensamento científico e o reducionismo cartesiano, amalgamado à arquitetura jurídica das codificações civis da Europa e da América do Sul - tanto as do ontem, como as de hoje -, certamente, estão entre os pilares de sustentação de um Direito disseminador de "uma tutela genérica e ineficaz" que ora ignora a existência de realidades jurídicas merecedoras de atenção e ora interfere em contextos nos quais não teria por que se imiscuir (FACHIN, 2011, p. 6).

Tais Códigos, aliás, ao desprezarem o fato de que o Direito existe também fora deles - tratando como proscritas as personagens das histórias não codificadas - e que a vida é prenhe de particularidades - negando a faticidade quando, arrogantemente, impõem respostas idênticas, ora para solucionar perguntas com conteúdo distinto, ora para responder a indagações que ainda não conhecem -, atuam como pitonisas incapazes de gerir a miríade de conflitos que pululam entre os tons e os sons inspiradores do existir humano, oráculos que não notam que fotografias (HIRONAKA, 2008, p. 50) não reveladas também podem precisar de cuidados.

E, se parte desses negativos revelará situações nas quais, apesar de possível, não houve o convívio entre pais e filhos, tema efervescente no Brasil de hoje (STJ, REsp 1.159.242/SP) ${ }^{1}$, noutros casos, os registros mostrarão, talvez, a necessidade da presença do Direito em histórias não contadas pelas codificações civis, dentre elas, as que se assemelham pelo viés da multiparentalidade, uma das muitas arquiteturas que retratam a vida de pessoas que não se sujeitaram a habitar um dos cômodos construídos pelas codificações civis.

Nessa toada, enquanto a arte imita a vida e a ficção deixou de estar pautada em uma lógica excludente, que buscava identificar, a qualquer custo, quem teria o direito de ser mãe ${ }^{2}$, preocupando-se, agora - a partir de uma matriz nutrida pela racionalidade

1 Consoante se extrai do julgado "[i]nexistem restrições legais à aplicação das regras concernentes à responsabilidade civil e o consequente dever de indenizar/compensar no Direito de Família. 2. O cuidado como valor jurídico objetivo está incorporado no ordenamento jurídico brasileiro não com essa expressão, mas com locuções e termos que manifestam suas diversas desinências, como se observa do art. 227 da CF/88. 3. Comprovar que a imposição legal de cuidar da prole foi descumprida implica em se reconhecer a ocorrência de ilicitude civil, sob a forma de omissão. Isso porque o non facere, que atinge um bem juridicamente tutelado, leia-se, o necessário dever de criação, educação e companhia - de cuidado - importa em vulneração da imposição legal, exsurgindo, daí, a possibilidade de se pleitear compensação por danos morais por abandono psicológico. 4. Apesar das inúmeras hipóteses que minimizam a possibilidade de pleno cuidado de um dos genitores em relação à sua prole, existe um núcleo mínimo de cuidados parentais que, para além do mero cumprimento da lei, garantam aos filhos, ao menos quanto à afetividade, condições para uma adequada formação psicológica e inserção social. 5. A caracterização do abandono afetivo, a existência de excludentes ou, ainda, fatores atenuantes - por demandarem revolvimento de matéria fática - não podem ser objeto de reavaliação na estreita via do recurso especial."

2 Na novela Barriga de Aluguel (Brasil, Rede Globo, 20.08.90 a 01.07.91), Ana (Cássia Kiss) e Zeca (Victor Fasano) foram informados pelo médico, Dr. Barone (Adriano Reys), que Ana não poderia engravidar. Ele informou o casal sobre a possibilidade de contratarem alguém para gestar o bebê. Eles contratam Clara (Claudia Abreu), moça simples, de família pobre, que vê uma boa oportunidade de melhorar de vida cedendo o útero para o casal e, assim, em troca de U\$20.000.00, Clara concordou em gestar o bebê. Durante a gestação, foi tomada 
inclusiva -, em discutir se é possível pensar - e, nesse caso, qual a melhor maneira de promover a conformação jurídica de tais estruturas familiares - em meus pais e minhas $m \tilde{a} e s^{3}$, no mundo real, exsurgem miríades de situações não imaginadas pela racionalidade codificadora da Modernidade (COING, 1982).

As reflexões aqui tecidas têm em conta que, se anteontem, a discussão estava centrada nos direitos de bastardia (BAPTISTA DE MELLO, 1933, p. 5-6) ${ }^{4}$ e, ontem, no direito de ter um pai (FACHIN, 1992, p. 43-115), hodiernamente, as preocupações do Direito devem dirigir-se, também, ao fenômeno da multiparentalidade, que tangencia: (a) o movimento incessante de construção e de destruição dos laços afetivos nas famílias recompostas (TEIXEIRA, RODRIGUES, 2010, p. 97); (b) a utilização de material genético de alguém como matéria-prima na fecundação de um novo ser (GIORGIS, 2007, p. 5860); (c) a adoção não destruidora do passado; (d) a gestação de substituição ou, ainda, (e) a história dos núcleos de poliamor. Transitam, ainda, considerando a complexidade do problema e o fato de que as famílias se reinventam a todo o tempo, assumindo conformações nas quais poderá haver (a) apenas duas mães (TJRS. Ap. Cív. 70013801592) ou (b) dois pais, (c) duas mães e um pai ${ }^{5}$, (d) dois pais e uma mãe, (e) duas mães e dois pais $^{6}$, (f) três mães e dois pais (FONTELES, 1987, p. 13) etc., vivendo (ou não) em harmonia. ${ }^{7}$

pela emoção da maternidade e, ademais, o parto, complicado, a deixou estéril, o que acabou motivando-a, ainda mais, a fugir com a criança, o que disparou uma disputa judicial pela guarda do menino que, ao final, foi entregue à mãe biológica.

3 Em A vida da gente (Brasil, Rede Globo, 26.09.2011 a 02.03.2012), Júlia (Jesuela Moro) desenha a árvore genealógica da família afirmando que essa será diferente: terá duas mães (a biológica e a socioafetiva) e dois pais (o biológico - Rodrigo (Rafael Cardoso) - e Lúcio, que é namorado da mãe biológica). A menina, criada como filha, pela tia Manuela (Marjorie Estiano), surpreende ao dizer que Lúcio (Thiago Lacerda) também é um pai para ela. "Ele é namorado da mãe biológica - Ana (Fernanda Vasconcellos), da qual foi separada por anos -, cuida de mim, me pega no colo, conta história." Vale destacar que, no final da novela, a menina continua afirmando ter duas mães.

4 Com o autor vale apontar que "nasceram de uniões [ilegítimas, gênios como] Boccacio, Erasmo [...] Savage, Emilio de Girardin, Dupanloup, o Mestre de Aviz e tantos outros."

5 Capturado em < http://wwwl.folha.uol.com.br/equilibrioesaude/888499-fertilizacao-com-duas-maese-um-pai-e-avaliada-no-reino-unido.shtml>, em 19.05.2012. "O óvulo da doadora é fertilizado, e seu núcleo, retirado. O óvulo da mãe também é fertilizado para ter só o núcleo fundido ao óvulo da doadora. Desse modo, as mitocôndrias do óvulo da mãe não passam para o embrião. Mitocôndrias são partes da célula que produzem energia e carregam genes que podem causar doenças como cardiopatias e distúrbios cerebrais. $\mathrm{O}$ embrião resultante vai herdar a maioria das características genéticas da mãe, mas não os genes defeituosos."

6 Capturado em <http://www.rnw.nl/portugues/article/duas-maes-e-dois-pais >, em 19.05.2012. Segundo a matéria, Max e Robin têm dois pais e duas mães, dividindo seu tempo entre a casa da mãe biológica, Annemiek, a da mãe adotiva, Jeanine, a casa do pai biológico, Jonatas e do pai emocional Hubert Roza. Elas queriam ter filhos. Precisavam de um doador de esperma. Consultaram Jonatas e Hubert. Para Annemieke, seria importante que o doador desempenhasse o papel de pai. Decidiram que Jonatas seria o pai biológico. Na Holanda, apenas duas pessoas podem se responsabilizar por uma criança. A mãe biológica tem a guarda e a parceira, a mãe social, está autorizada a adotar. No caso, o pai biológico, Jonatas, e o pai emocional, Hubert, são tutores dos meninos.

7 Capturado em < http://noticias.terra.com.br/mundo/noticias >, em 19.05.2012. "Um menino britânico de dois anos com “duas mães e um pai” está no centro de uma batalha judicial incomum, na Grã-Bretanha. A mãe 
Daí que um olhar prospectivo para o tema poderá informar a conformação jurídica de incontáveis celeumas havidas nos mais distintos rearranjos familiares sem a necessidade de discutir - a partir da matriz binária e excludente que informa as codificações do presente - a quem será atribuída a maternidade (MEIRELLES, 1998, p. 93-101) ou a paternidade daquele que é tratado como um filho, impondo-se à comunidade a assunção do desafio de ultrapassar os simplismos contidos na lógica "os meus, os seus e os nossos filhos" (VALADARES, 2008, p. 148), até porque - descendente biológico (ou não) -, "toda criança precisa ser adotada psiquicamente por seus pais" (FONTELES, 1987, p. 129). Um bom ponto de ancoragem para pensar a multiparentalidade parece estar nos mosaicos familiares (FERREIRA, 2006, p. 509) ${ }^{9}$, também conhecidos por famílias pluriparentais, refeitas, reconstituídas, reorganizadas (WAGNER, 2002, p. 24-26) ${ }^{10}$, recompostas (RUZYK, 2005), patchwork, ensambladas, step-families ou recomposées (FERREIRA, 2006, p. 508).

$\mathrm{E}$ isso porque estudos realizados no Brasil apontam que nelas, enquanto o pai biológico tende a tornar-se um coadjuvante nos enredos da história de cada vida real demonstrando "menor afetividade" e, ao mesmo tempo, maior parcimônia com as más escolhas feitas pelos filhos -, o novo parceiro da mãe - normalmente, com o apoio e auxílio desta - assume, não apenas, a função de gestor das despesas cotidianas, mas também a de autoridade hierárquica na condução de uma família que tende a se reinventar a partir: (a) da assunção de papéis mais densos - e mais dinâmicos - pela mãe que vive um novo amor; (b) da manutenção do diálogo com aquele que tende a ser extirpado do convívio cotidiano; (c) da ampliação da complexidade dos roteiros individuais e coletivos no novo grupo familiar; (d) da percepção de que novas uniões são boas para os genitores;

biológica diz ter feito um "pacto" com o pai, antes de o menino ser concebido, de que ela e sua parceira lésbica seriam as "mães" e de que ele teria contato limitado com a criança. Agora, as mulheres dizem se sentir "amarguradas e traídas", depois que o pai pediu à Justiça que o filho durma em sua casa ocasionalmente e passe férias com ele, bem mais do que as atuais cinco horas a cada 15 dias que ele passa com a criança. $O$ pai argumenta que ele sempre foi bem mais do que um "doador de sêmen", já que esteve presente durante o nascimento do bebê, seu batizado [etc.e quer] ser um pai de verdade para o único filho que terá na vida."

8 Defende a autora a atualidade do brocardo mater sempre certa est especialmente porque "a participação da 'mãe geradora' é fundamental do ponto de vista biológico."

9 Apontando a autora que "[a] mais conhecida era a recomposição em caso de viuvez. Atualmente, ressurge como fenômeno social que em decorrência da notável expansão passa a compor modalidade familiar com características próprias e especificidades complexas, coexistindo com a família tradicional. [...] Fator significativo repousa no crescimento desta opção de organização familiar, mais que isto, na flexibilidade de sucessivas recomposições."

${ }^{10}$ Afirma, ainda, a autora que a "complexidade já aparece frente à necessidade de nomear esses novos membros, fazendo surgir diferentes nomenclaturas nos seio destas famílias e no contexto onde elas se inserem. As palavras madrasta, padrasto e enteado(a), por exemplo, ressurgem na tentativa de nomear a relação entre pessoas que não possuem vínculo de consanguinidade e passam a fazer parte da família. Entretanto, sabe-se que estas terminologias, desde as histórias infantis, vêm carregadas de conotações pejorativas e caracterizam relações familiares muito difíceis [...] e, até mesmo, insustentáveis." 
(e) da boa relação, normalmente havida, entre os filhos da relação anterior (WAGNER, 2002, p. 29-35) e os novos parceiros de seus pais e, enfim, mas não exaustivamente, (f) da identificação de que cada pessoa é única e que, por isso, não precisa corporificar uma personagem marcada pela atuação daquele que não mais irá exercê-la (FALCKE, 2002, p. 85-88).

É evidente que pensar o tema é algo desafiador quando se tem em mente a existência de regras que, apesar de reconhecerem que o parentesco pode não ser biológico $^{11}$, o estruturam a partir da ligação - efetuada por meio de ficções jurídicas: as presunções de paternidade e de maternidade - de cada pessoa a um tronco familiar ${ }^{12}$ do qual quem nasce não pode desligar-se voluntariamente ${ }^{13}$, embora, paradoxalmente, ramos dessa árvore possam ser podados, a qualquer tempo, por aquele a quem se atribui a paternidade. ${ }^{14}$

Instigante, ainda, por se considerar a existência de regras que, apesar de não atribuírem ao parceiro do genitor o poder de ingerência na condução dos destinos dos filhos do último ${ }^{15}$, ditando, cartesianamente, que ele (ou ela) não detém autoridade parental (TEIXEIRA; RODRIGUES, 2009, p. 43), concede-lhe, paradoxalmente, o poder de impedir que aquele resida em seu domicílio conjugal ${ }^{16} \mathrm{e}$, portanto, o poder de tratar o filho do outro como filho do outro, o que não assusta, quando se recorda que o Estatuto da Criança e do Adolescente impede que a adoção de menor de idade seja concedida a duas pessoas que não vivam no mesmo ninho conjugal. ${ }^{17}$

${ }^{11}$ CC. Art. 1.593. O parentesco é natural ou civil, conforme resulte de consanguinidade ou outra origem.

12 CC. Art. 1.592. São parentes em linha colateral ou transversal, até o quarto grau, as pessoas provenientes de um só tronco, sem descenderem uma da outra.

${ }^{13}$ Senão e desde que observados determinados requisitos, consoante a legislação vigente no Brasil, por meio da adoção, após a maioridade civil, ou consoante previsto na codificação, nos moldes do art. 1.614, nas hipóteses em que tenha havido o reconhecimento de paternidade de filho menor de idade, situação que, a nosso sentir, só poderá ser levada adiante, é evidente, desde que não haja laços de socioafetividade imantando a relação parental estabelecida concretamente.

${ }^{14}$ CC. Art. 1.601. Cabe ao marido o direito de contestar a paternidade dos filhos nascidos de sua mulher, sendo tal ação imprescritível. Por ora, saliente-se, apenas, a regra que trata do tema na codificação civil brasileira vigente, vez que a temática será retomada mais à frente. Aliás, aponte-se, ainda, que a reflexão, obviamente, não tem em conta os efeitos jurídicos da socioafetividade.

${ }^{15}$ CC. Art. 1.636. O pai ou a mãe que contrai novas núpcias, ou estabelece união estável, não perde, quanto aos filhos do relacionamento anterior, os direitos ao poder familiar, exercendo-os sem qualquer interferência do novo cônjuge ou companheiro.

${ }^{16}$ CC. Art. 1.611. O filho havido fora do casamento, reconhecido por um dos cônjuges, não poderá residir no lar conjugal sem o consentimento do outro.

17 ECA. Art. 42 [...] $\$$ 4 Os divorciados, os judicialmente separados e os ex-companheiros podem adotar conjuntamente, contanto que acordem sobre a guarda e o regime de visitas e desde que o estágio de convivência tenha sido iniciado na constância do período de convivência e que seja comprovada a existência de vínculos de afinidade e afetividade com aquele não detentor da guarda, que justifiquem a excepcionalidade da concessão. 
Assim, imersos em "tempos frutíferos de inquietude [que] denunciam dilemas expostos na fratura social, arrostam a exclusão econômica e jurídica e apontam para a força criativa dos fatos sociais" (FACHIN, 2000, s./p.), tendo por método uma postura crítica atrelada às correntes pós-positivistas do Direito (CÁRCOVA, 2009) e, por objetivo, a conformação de conflitos identificados nas realidades outrora descritas, cada linha aqui tecida intenta contribuir com a promoção do bem comum, sonhando - uma utopia factível - com a localização das trilhas que conduzirão ao porvir.

\section{EM BUSCA DE PEgadas APAgAdas PELO TEMPo}

Oportuno identificar que os laços de parentalidade - essa construção cultural - nem sempre estiveram atados à racionalidade binária e excludente que informa, dentre outros, os Códigos Civis brasileiros de 1916 e de 2002. Ultrapassando os limites impostos por estruturas cognitivas pré-moldadas, as relações de parentalidade, ao longo da história da humanidade, foram coloridas com distintos tons e variadas cores, sem que qualquer uma dessas representações fosse exaltada como a pintura ideal: todas eram igualmente belas.

Fosse possível voltar no tempo e, provavelmente, identificar-se-iam momentos nos quais a voz de comando da autoridade familiar era outorgada ao tio materno (GILISSEN, 1988, p. 39). ${ }^{18}$ Essa diretriz cultural não desprezava o papel do genitor - ele possuía outras funções na formação dos pequenos - ou causava problemas na formação dos últimos. Esse modo de vida conduzia, apenas, a um equilíbrio distinto do conhecido contemporaneamente na formação do psiquismo de seres humanos (LACAN, 2008, p. 54). Em tais relações é interessante apontar, o bloqueio dos conflitos edipianos favoreceria, supostamente, o desenvolvimento de relações amistosas entre os genitores e aqueles por eles gerados, como demonstram estudos realizados em tribos da Austrália e da Nova Guiné, nas quais, consoante antecipado, deslocava-se a autoridade do pai para o tio materno e, em povos do antigo Alto Volta - atual Burquina Fasso, na África que a atribuíam a um tio paterno (PARSEVAL, 1986, p. 23).

E há realidades ainda mais encantadoramente díspares do que a chancelada contemporaneamente como padrão na atribuição dos vínculos de parentalidade. Entre elas, a vivida pelos Iroqueses - e outros grupos indígenas norte-americanos -, povo que acredita que seus filhos são tanto os nascidos de quem se relaciona com a mãe que os gera, como os filhos de seus irmãos, embora, tratem os filhos de suas irmãs como sobrinhos. Inversamente, as iroquesas tratam como filhos os que dela descendem biologicamente e os concebidos por suas irmãs, mas não os dos seus irmãos, tratados como sobrinhos (ENGELS, 1984, p. 63).

\footnotetext{
${ }^{18}$ São "da mesma família: a mãe, os seus filhos, os filhos das suas filhas, os filhos das netas das suas filhas etc."
} 
Entre os Tibetanos, todos os maridos são pais, atribuindo-se, entretanto, ao mais velho, dentre eles, lugar de destaque e, talvez, a última palavra quando surjam conflitos envolvendo o exercício desses papéis. Na Índia, entre os nayars, os atributos atados ao exercício da paternidade pertencem a vários homens (PARSEVAL, 1986, p. 35-38).

$\mathrm{E}$, entre os mossi africanos, saliente-se não só que cada criança tem em média dez pais - aos quais são atribuídos papéis variáveis (BRITO, 2008, p. 14) -, como também a todas as mulheres da família da mãe é imputado o exercício desse papel (PARSEVAL, 1986, p. 43-44). Ademais, enquanto entre os $N a$, na China, as mulheres se entregam por uma noite ou pouco mais a cada homem e ninguém busca identificar quem é o pai (GIORGIS, 2009, p. 46-47), uma vez mais na África, e agora entre os bavendas, uma mulher pode ser mãe de um filho e pai de outro (PARSEVAL, 1986, p. 24-37). ${ }^{19}$

Enfim, ilustrativamente, aponte-se que os txicao - indígenas que vivem no estado do Mato Grosso, na região Centro-Oeste do Brasil -, por acreditarem que o embrião deriva exclusivamente do sêmen do pai, copulam várias vezes a mesma mulher, na tentativa de somar o que há de positivo em cada habitante da tribo, ideia compartilhada pelos nhambiquaras e por tantas outras etnias indígenas (PARSEVAL, 1986, p. 24) e que irá desaguar, tal qual noutras situações apontadas, no reconhecimento do fenômeno da multiparentalidade, sem que isso provoque conflitos entre tais povos.

A tentativa de resgatar a historicidade contida em alguns dos instantes mais importantes do processo de mutação sociocultural - na atribuição dos laços de parentalidade - havido desde as sociedades matrilineares da Antiguidade até o modelo de família forjado - e imposto - pela matriz de pensamento eurocêntrica, não pode ignorar que o abandono da vida nômade, o enaltecimento dos guerreiros e a construção da ideia de propriedade grupal conduziram ao surgimento da figura do chefe do clã que ocupa o lugar outrora atribuído ao irmão da mãe (GIORGIS, 2009, p. 53-55) ${ }^{20}$ - e deram primazia à virilidade masculina em detrimento da fraternidade feminina como norte a ser perseguido na condução dos destinos - e da história (!?) das famílias.

19 "Se a mulher for o único filho de um casal, seus genitores não podem ter descendentes através [sic] dela, pois o sistema de parentesco dessa população é patrilinear. Como tal situação é insuportável, eis a solução que se encontrou para as necessidades da causa: a mulher em questão não será mãe, e sim pai; desposará outras mulheres, que engravidarão de amantes masculinos oficiosos [o] que não a impede de ser mãe ao mesmo tempo [uma] vez casada com um homem."

${ }^{20}$ Curioso notar que a "paternidade não adquiriu demasiada importância enquanto não acarretou consequências notáveis em matéria de propriedade. Em compensação, esse interesse traz consigo a exigência da absoluta fidelidade conjugal da mulher, embora a do homem não tenha a mesma raiz, emergente talvez da igualdade entre os sexos e de um mandamento de simples justiça. [...] Os gregos proclamavam abertamente que os únicos objetivos da monogamia eram a preponderância do homem na família e a procriação de filhos que só pudessem ser seus para herdar." 
Os clãs (GILISSEN, 1988, p. 563-564) ${ }^{21}$ exsurgem como formas familiares rudimentares que permitem identificar um agregado de pessoas como uma estrutura familiar em razão dos interditos disseminados em seu interior (LACAN, 2008, p. 10-11) e as trocas estimuladas por esses.

E, enquanto, entre os Gregos, a ideia de propriedade privada surge da necessidade de saber, antecipadamente, a quem ela será transmitida, com a morte do titular, foi o que forjou a presunção pater ist est - presunção que não conseguiu extirpar essa dúvida do inconsciente de cada um dos homens -, como se percebe, a partir de uma matriz de pensamento explicitamente patrimonial, em Roma (GILISSEN, 1988, p. 81) 22, a apropriação da ideia e a construção de um direito de vida e de morte, atribuído ao marido - a quem incumbia conduzir os destinos de cada um dos seus e do seu templo (FUSTEL DE COULANGES, 2009, p. 53) 23 $^{23}$, sobre a esposa infiel, garantiria sua efetividade, ainda que essa mesma efetividade não passasse, uma vez mais, de outra ficção (ENGELS, 1984, p. 95-107) ${ }^{24}$ bem elaborada: às vezes, é melhor não saber.

A família romana perece ter sido uma associação religiosa estruturada, inicialmente, sob a forma de (a) gens (FUSTEL DE COULANGES, 2009, p. 113-126) ${ }^{25}$ e, mais tarde, arquitetada pela (b) agnatio (KASER, 1999, p. 96) ${ }^{26}$ ou pela (c) cognatio, ainda que os destinos de cada um dos seus integrantes tenham estado, em princípio e invariavelmente,

21 “Como a lei do mais forte predomina nas sociedades arcaicas, os membros do mesmo clã terão tendência a reforçar os laços que os unem de maneira a poderem fazer frente aos inimigos comuns. Estes laços vão subsistir para além da pessoa física dos indivíduos, mesmo depois da morte. [...] $\mathrm{O}$ clã encontra-se na origem da maior parte das civilizações. [...] $\mathrm{O}$ clã tem geralmente um nome; tem mitos e rituais próprios, interdições alimentares [e o] desenvolvimento e mesmo a sobrevivência do clã depende da coesão dos seus membros [que] estão ligados entre si por uma solidariedade tanto activa como passiva." Ele é estruturado na solidariedade grupal, solidariedade que une a família (a) na vingança privada, (b) no dever de reparar os danos provocados a outrem por um integrante do clã e, no (c) dever imposto a todos os integrantes do grupo de jurar inocência quando necessária à administração da justiça, e que desaparece gradualmente com o desenvolvimento do Estado Moderno.

${ }^{22}$ Vale lembrar que o direito romano pode ser dividido em "[a] uma época antiga, até meados do século II a.C., período do "direito romano muito antigo", direito de tipo arcaico, primitivo, direito duma sociedade rural baseado sobre a solidariedade clânica; [b] uma época clássica (de cerca de 150 a.C. a 284 d.C.), a do "direito romano clássico", direito duma sociedade evoluída, individualista, direito fixado por juristas numa ciência jurídica coerente e racional; [c] a época do Baixo Império, direito nascido da tripla crise do século III, política, econômica e religiosa, direito dominado pelo absolutismo imperial, pela atividade legislativa dos imperadores, pelo Cristianismo."

23 "A família era um grupo de pessoas a que a religião permitia invocar o mesmo lar e oferecer o banquete fúnebre aos mesmos antepassados."

${ }^{24}$ Fidelidade, portanto, que se exige - ou que se impõe em perspectiva ficcional - quando surge a necessidade de ter descentes a quem serão transmitidos os bens havidos em vida pelo ascendente.

25 "A gens [...] formava um corpo cuja constituição era totalmente aristocrática." Uma família que se desenvolve sem se dividir e na qual "[v]ários ramos mais jovens permanecem agrupados ao redor de um ramo primogênito, junto à lareira única e à tumba comum."

26 “A condição de membro dessa associação doméstica submete o indivíduo ao pleno poder e quase ilimitado do paterfamilias que se manifesta em graus diversos consoante os seus objetos." 
em quaisquer das molduras, sujeitos aos poderes atribuídos ao titular da pátria potestas (PEREIRA, 2008, p. 29). ${ }^{27}$

É bastante provável, também, que, de Cícero $^{28}$ a Justiniano ${ }^{29}$, as relações de parentesco decorrentes da agnatio e as reconhecidas em razão da cognatio tenham coexistido; não sem conflito (FUSTEL DE COULANGES, 2009, p. 71), observando-se, ao tempo do último, a primazia da derradeira das formas, mormente quando se consideram os prováveis reflexos do ato político de conversão de Constantino ao Cristianismo. ${ }^{30}$

O Cristianismo, apesar de haver surgido entre os últimos séculos da Antiguidade Clássica e os primeiros da Idade Média, é certamente a vertente mais influente na formação da família contemporânea, reverberando, ainda hoje, na intelecção de incomensuráveis questões atadas àquela.

É preciso perceber, entretanto, que tais construções, em boa parte, decorrem da agressão à liberdade (PARSEVAL, 1986, p. 220) - supostamente existente outrora havida quando da transformação do casamento em sacramento (CABRAL, 2012, p. 55), da escravização do homem (ENGELS, 1984, p. 104) decorrente da transmutação dos desejos da carne em pecado e da disseminação do ódio contra todo aquele que pensasse de modo distinto (NIETZSCHE, 2012, p. 39), da proibição, portanto, do próprio pensar (NIETZSCHE, 2009, p. 44).

O casamento, uma bênção (FERREIRA, 1939, p. 4) e muitas dúvidas, dentre as quais, a que busca saber (a) se haverá efetiva comunhão de vidas entre marido e mulher (FACHIN, 2003(b), p. 62), agora condenados a viverem como um só até que a morte os separe - sendo indissolúvel, o casamento exigia, para sua validade e vigência, apenas a observância de algumas formalidades durante a celebração e a ulterior consumação sexual -, (b) se o amor exsurgirá, entremeio aos arranjos econômicos, que precederam à realização das núpcias, ou (c) se a promessa de fidelidade - jurada perante o outro, no sacrossanto altar - será quebrada na primeira oportunidade que ele (ou ela) tenha.

O casamento - um dos ninhos para o amor verdadeiro -, quando visto a partir de sua historicidade, exsurge como reflexo do aprimoramento bem elaborado de construções pretorianas que visavam facilitar a sujeição da mulher aos desejos do marido e garantir por meio de mais uma ficção - que cada filho dela fosse, também, um filho dele. Um

27 "O pater é o sacerdote, é o senhor e o magistrado dentro de sua casa. As pessoas, que compõem a família, não estão sujeitas à jurisdição da civitas, mas à do pater", contexto que sofreu mutações provocadas pelo inconstante labor do tempo ao tempo do Direito Romano.

${ }^{28}$ Marco Túlio Cícero viveu entre 106 e 43 a.C.

${ }^{29}$ Imperador Bizantino, que reinou entre 527 a 565 d.C.

${ }^{30}$ Constantino entrou para a História como o primeiro imperador romano a professar o cristianismo, tendo governado Roma de 307 até 337 d.C. Sob seu comando, houve a publicação do Édito de Milão (313), por meio do qual Roma se declarou neutra em relação à religião professada por seus cidadãos. 
sacrifício que exigia - e exige, mesmo hoje - a castração da sexualidade feminina (PEREIRA, 2003, p. 99-101) e que ainda se sustenta na proibição do desejo (PEREIRA, 2003, p. 30-31) $)^{31}$ e em um discurso que envia as almas das pecadoras para o Inferno.

O curioso é que a mesma lógica que dissemina - durante a Idade Média e mesmo depois de a Ciência ter ocupado o lugar de Deus na condução dos desígnios da humanidade - que os filhos têm "direito à vida, a uma ajuda material e moral durante a juventude", despreza os nascidos fora do casamento (GILISSEN, 1988, p. 612), enviando - como antecipado - ao Inferno tudo que estiver em seu caminho (NIETZSCHE, 2012 , p. 81), até mesmo os filhos de seus sacerdotes: tratados como sacrílegos, com eles serão enviados ao Hades os filhos adulterinos, os espúrios e, no Brasil, também os filhos dos peões, ao menos até 1847, em razão do tratamento discriminatório dado a eles quando comparados com os filhos dos barões (BOSCARO, 2002, p. 62).

$\mathrm{E}$, apesar de a afetividade ser percebida como a amálgama das relações familiares a partir de meados do século XVIII (PAULO, 2009(a), p. 43-44) - por causa das relações proletárias, vez que entre a aristocracia decadente e a burguesia em ascensão, os casamentos ainda eram um bom negócio, e nada mais (ENGELS, 1984) -, no Brasil, a virilidade patriarcal e a racionalidade patrimonialista foram os vetores que informaram a codificação que veio a lume em 1916 (ALBUQUERQUE JÚNIOR, 2006-2007, p. 53).

Tudo isso causou marcas indeléveis na história da família contemporânea, estrutura que não tem como ser aprisionada no interior de um código e que varia consoante o espaço e o tempo nos quais tenha que ser pensada (GOMES, 1984, p. 61), tanto que, ainda hoje, as verdades parentais continuam sendo pensadas como teleologias despidas de cientificidade (PARSEVAL, 1986, p. 21) e, assim, apesar de alusões constantes à personalização e à constitucionalização do Direito, a tutela do patrimônio continua a informar o senso comum imaginário dos juristas e a lógica que antecede cada carimbo moldado nas regras codificadas.

Esse passeio através do tempo permite compreender, agora, como a racionalidade patrimonialista e individualista, que, aparentemente informou a Antiguidade Clássica e a Idade Média, continua a impregnar - mesmo que isso, normalmente, não seja percebido parte das regras contidas na codificação vigente e os raciocínios dos que se propõem a pensá-la. Perceba o leitor que isso acontece - e esse detalhe, consoante o prisma eleito, pode ser deveras assustador - nos albores do Século XXI, em uma passagem do tempo na qual não só a máxima mater semper certa est é mais e mais questionada, mas também na qual, em lugar do pater ist est (LÔBO, 2010, p. 195), o father who knows (PARSEVAL,

${ }^{31}$ Embora, como aponta o autor, "[e]nquanto houver desejo, ele sempre escapará ao normatizável [apesar de o Estado supor] que poderia controlar as relações sexuais, estabelecendo que estas só poderiam existir dentro do casamento." 
1986, p. 14) $)^{32}$ - que tanto mal-estar tem causado a civilização ocidental - convive com os influxos que emanam (ou não) dos laços amor - e com a energia polarizadora da socioafetividade -, imantando as realidades vividas em cada núcleo familiar.

Ora, se a "família é uma estrutura de afetividade" (NOGUEIRA, 2001, p. 61), uma estrutura arquitetada nesse valor do Direito contemporâneo, não há como aceitar que estrelas errantes (FACHIN, 2004, p. 369-373) possam ter seu brilho ofuscado pela escuridão atemporal que informa parte da dogmática que continua a ser construída no Brasil, mesmo porque, apesar de vozes dissonantes ${ }^{33}$, as verdades parentais não mais podem ser vistas como entes pré-moldados.

Elas são construídas (VERUCCI, 2000, p. 91) no tempo e no espaço do convívio cotidiano (PAULO, 2009(a), p. 56-57) e é por isso que o parentesco não está atado, necessariamente, à vinculação genética ou a outra moldura excludente, qualquer que seja ela. Também, por isso, se várias pessoas exercem, concomitantemente, as funções parentais, é que será possível distribuir a cada uma delas direitos e deveres conexos a esses papéis - os papéis parentais -, até porque - ao menos assim nos parece -, hodiernamente, raramente apenas um homem e uma mulher são os protagonistas dessas histórias (PARSEVAL, 1986, p. 215). ${ }^{35}$

O desafio está posto: ele consiste em ultrapassar o legado reducionista que contamina o direito codificado - um pai, uma mãe - e a redimensionar as possibilidades normativas contidas no universo das relações pluriparentais, fortalecendo as realidades familiares e estimulando a assunção de responsabilidades, atentando, assim, às necessidades de um ser humano concreto - pensado como ser no mundo - e para a centralidade por ele ocupada em um sistema jurídico (FACHIN, 2006, p. 14-15) que pretende ser democrático e de direito.

32 Dentre as quais, estão "o sobrenome dado pelo pai, o reconhecimento paterno, se se tratar de um filho concebido fora do casamento, as diversas obrigações jurídicas para o sustento dos filhos, os procedimento de reconhecimento de paternidade" sem contar a regra contida no Code Napoleón, versando acerca do "pater est quem nuptiae demontrant".

33 Acerca da interferência de elementos classificados como tradicionais e transgressores na formação dos laços de parentalidade: HERRERA, Florencia. La otra mamá: madres no biológicas en la pareja lésbica. In: GROSSI, Miriam; UZIEL, Anna Paula; MELLO, Luiz (Org.). Conjugalidades, parentalidades e identidades lésbicas, gays e travestis. Rio de Janeiro: Garamond, 2007. p. 231.

34 “A idéia de que haveria uma ligação exclusiva da criança com a mãe, de um instinto poderoso desta para cuidar dos filhos é produto da cultura patriarcal que colocou a mulher trancada na sua maternidade, confundindo sua vida com a vida dos filhos [...]."

35 "Numerosas personagens, reais ou imaginárias, contribuem para a concepção (ou a não-existência) de uma criança: antepassados, avós, irmãos e irmãs, tios, tias, sobrinhos, sobrinhas, primos, fadas madrinhas ou bruxas malvadas, agitam-se em volta do leito nupcial [...]" 


\section{MULTIPARENTALIDADE: RETOMANDO A PICADA RUMO AO PORVIR}

Cada família - qualquer que seja a moldura eleita - deve ser pensada como uma unidade funcionalizada à realização de todos - e, portanto, de cada um - aqueles que a compõem (LÔBO, 2004, p. 138-139), e não mais como uma estrutura protegida apenas enquanto tal. A aceitação dessa premissa impõe - também ao Direito - a valorização do convívio de todos os que se encontram ligados na faticidade das relações de parentalidade. ${ }^{36}$ A filiação é uma "construção cultural, fortificada na convivência [e] no entrelaçamento" de afetividades (LÔBO, 2010, p. 270) rearranjadas na mesma toada em que os papéis parentais são representados (TEIXEIRA; RODRIGUES, 2010, p. 98) por múltiplos atores cotidianamente. E isso, aponte-se aqui, independentemente da coincidência de tais laços com os moldes codificados.

Quando se percebe a relação de parentalidade (a) como algo que ultrapassa a conexão biológica existente entre duas (ou mais) pessoas (PAULO, 2009(b), p. 26), identificando que ela é (b) mais que uma simples autorização - para o exercício de direitos patrimoniais - dada pela codificação e que (c) ser pai e (ou) ser mãe são papéis (PEREIRA, 2003, p. 54) - importantes, não há dúvidas -, funções simbólicas a serem representadas (BARROS, 2001, p. 110-113) ${ }^{37}$ (ou não) por pessoas de carne e osso, com sangue, amor e ódio (ou não) no coração, não há como refutar a ideia de que cada uma dessas funções poderá (ou não) ser atribuída, concomitantemente, a mais de uma pessoa e exercidas, ao mesmo tempo (ou não), por cada uma delas.

Ademais, não há como negar que devem ser afastados - no mínimo, redimensionados - do discurso (d) o fetiche geneticista - que por pouco não destruiu as possibilidades de construção de todo o arcabouço teórico de sustentação da socioafetividade (LÔBO, 2008, p. 6) ${ }^{38}$ - e (e) as regras excludentes que informam cartesianamente a codificação vigente, o que ocorre em razão do reconhecimento de que os laços imantados pela socioafetividade podem sobrepor-se aos gestados geneticamente (PEREIRA, 2010-2011, p. 117), para o mal e para o bem (GROENINGA, 2008, p. 74-77). A percepção dessas questões permite que a normatividade alcance - também - as relações multiparentais, freando o processo de reconhecimento - e valorização, ainda que inconsciente - de inclusões excludentes

${ }^{36} \mathrm{E}$, é evidente, também nos núcleos de conjugalidade, excluídos do texto, apenas para evitar ampliar, ainda mais, a complexidade que permeia a temática.

37 "Na contemporaneidade, o lugar do pai apresenta-se na sua pluralidade. Seja o pai Estado, pai biológico, pai professor, pai namorado da mãe, pai vovô, padre-pater, papai do céu, pai herói, pai bandido. Todos interferem na operação de constituição da criança."

38 A hipervalorização do exame de DNA (como prova genética dos laços de parentalidade) por pouco não mudou os rumos da história das relações de parentalidade no direito brasileiro contemporâneo. 


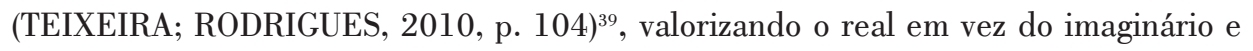
disseminando, se necessário, a sobreposição de funções, sem desprezar, nem privilegiar, nenhum ator social.

Abra-se um rodapé no texto: antes de permitir o surgimento de outras letras que, rabiscadas uma a uma, possam se transformar em signos e significados unidos no texto e no contexto - que possam despertar outras reflexões no diálogo proposto com o leitor, aponte-se que o significado atribuído à afetividade - assim pensada ou sob a forma de socioafetividade - não pode ser confundido com o dado ao afeto (LÔBO, 2008, p. 9) ${ }^{40}$, premissa que nem sempre tem sido respeitada e que, por isso, respalda a construção de soluções que devem ser qualificadas, muitas vezes, no mínimo, como deveras questionáveis (STJ, REsp 833712/RS). ${ }^{41}$

Encontrar as trilhas que poderão conduzir ao porvir exige (a) ultrapassar a compreensão exegética do texto constitucional e nele identificar que cada uma das formas ali contidas ${ }^{42}$ é apenas mais uma forma - dentre outras, conhecidas (ou não) - de conformação de uma entidade familiar o que pode ser realizado mediante a ressignificação prospectiva (FACHIN, 2009, p. 248) da ideia de família ${ }^{43}$, realidade a ser pensada a partir da existência de cada pessoa que busca se encontrar no outro o que permitirá construir, diuturnamente, cada singularidade (FACHIN, 2011, p. 9-13).

Enfim, uma vez (a) reconstruído e compreendido o processo de atribuição dos laços de parentalidade nas sociedades eurocêntricas, (b) detectada a existência de incontáveis nichos de multiparentalidade espalhados nos meandros da vida e (c)

${ }^{39} \mathrm{E}$ isso porque "[a] ideia ainda amplamente difundida é que o reconhecimento de um vínculo de paternidade ou maternidade deve gerar a exclusão do outro."

40 A afetividade é um valor detectado objetivamente na intersubjetividade da relação e não se confunde com a subjetividade que imanta a significação dos afetos.

41 “A investigante não pode ser penalizada pela conduta irrefletida dos pais biológicos, tampouco pela omissão dos pais registrais, apenas sanada, na hipótese, quando aquela já contava com 50 anos de idade. Não se pode, portanto, corroborar a ilicitude perpetrada, tanto pelos pais que registraram a investigante, como pelos pais que a conceberam e não quiseram ou não puderam dar-lhe o alento e o amparo decorrentes dos laços de sangue conjugados aos de afeto. Dessa forma, conquanto tenha a investigante sido acolhida em lar "adotivo" e usufruído de uma relação sócio-afetiva, nada lhe retira o direito, em havendo sua insurgência ao tomar conhecimento de sua real história, de ter acesso à sua verdade biológica que lhe foi usurpada, desde o nascimento até a idade madura."

${ }^{42}$ CF. Art. 226. A família, base da sociedade, tem especial proteção do Estado. $\S 1^{\circ}-0$ casamento é civil e gratuita a celebração. [...] $\S 3^{\circ}$ - Para efeito da proteção do Estado, é reconhecida a união estável entre o homem e a mulher como entidade familiar, devendo a lei facilitar sua conversão em casamento. $\S 4^{\circ}$ - Entende-se, também, como entidade familiar a comunidade formada por qualquer dos pais e seus descendentes.

${ }^{43} \mathrm{CF}$. Art. 227. É dever da família, da sociedade e do Estado assegurar à criança, ao adolescente e ao jovem, com absoluta prioridade, o direito à vida, à saúde, à alimentação, à educação, ao lazer, à profissionalização, à cultura, à dignidade, ao respeito, à liberdade e à convivência familiar e comunitária, além de colocá-los a salvo de toda forma de negligência, discriminação, exploração, violência, crueldade e opressão. 
identificada a possibilidade de cada um deles ser constitucionalmente tutelado, talvez ainda seja relevante derrubar um último ídolo: o amor materno não é incondicional; ele pode não existir (PAULO, 2009(a), p. 56). ${ }^{44}$

Agora talvez seja mais fácil compreender e aceitar por que levar o Direito até essas pessoas (FERREIRA, 2006, p. 512) 45 $^{5}$ e por que isso faz pulular indagações como (a) a que leva a perquirir se alguém precisaria escolher um entre dois (ou mais) pais (TJRS, Ap. Cív. 70029363918) ${ }^{46}$ (ou mães), quando tais funções podem ser sobrepostas, a que (b) transita em busca de conhecer como os mesmos motivos invocados para negar direitos a alguém (GIORGIS, 2009, p. 72) 47 $^{47 o}$ podem ser utilizados para reconhecer a existência de normatividade na multiparentalidade e, por ora, a que (c) conduz a questionar se uma certidão de nascimento pode transformar alguém em pai ou mãe (VALADARES, 2008, p. 160).

Sonhar com utopias factíveis - sem a preocupação de identificar, aqui, se o percurso trilhado conduziu a conquistas ou foi conduzido por concessões (TJRS, Ap. Cív. $70031164676)^{48}$ - é possível quando se lembra (a) da possibilidade de alteração do nome

${ }^{44}$ Continua a autora afirmando que "[o] amor materno [é apenas] um sentimento humano e, como tal, é incerto, frágil e imperfeito [podendo] existir ou não existir, ser duradouro ou desaparecer, mostrar-se forte ou frágil, exclusivo de um filho ou igualmente repartido entre todos [e, nesse condão, pode, haver] uma gama de outros sentimentos, além do amor, ou ao invés dele, podem existir: ódio, raiva, rancor, indiferença, desprezo, inveja, ciúme, ou até mais de um deles, em distintas dosagens."

45 “A consolidação das posições e papéis vividos pelos casais no mosaico requer, igualmente, capacidade de adaptação. Não raro, o papel de pai - o mais comum - não se revela de imediato. Surgem figuras próximas como a dos clássicos "tio", "tia", ou amigos ou mesmo "o esposo de minha mãe", "a companheira de meu pai". Nesta fase, as autoridades paterna e materna são questionadas e desafiadas até conquistarem o status esperado. Enquanto os papéis não se definem as ambigüidades são próprias do momento das primeiras aproximações, típicas do reconhecimento entre aqueles que passam a compartilhar, verdadeiramente, suas próprias vidas, em nome do afeto."

46 "Mesmo havendo pai registral, o filho tem o direito constitucional de buscar sua filiação biológica (CF, $\S 6^{\circ}$ do art. 227), pelo princípio da dignidade da pessoa humana. O estado de filiação é a qualificação jurídica da relação de parentesco entre pai e filho que estabelece um complexo de direitos e deveres reciprocamente considerados. Constitui-se em decorrência da lei [...], ou em razão da posse do estado de filho advinda da convivência familiar. Nem a paternidade socioafetiva e nem a paternidade biológica podem se sobrepor uma à outra. Ambas as paternidades são iguais, não havendo prevalência de nenhuma delas porque fazem parte da condição humana tridimensional, que é genética, afetiva e ontológica [!?]."

${ }^{47} \mathrm{Na}$ lição do autor, para impedir o casamento entre irmãos ligados apenas pelos laços de socioafetividade. Veja, ainda, LC 64/90. Art. $1^{\circ}[\ldots] \S 3^{\circ}$ São inelegíveis, no território de jurisdição do titular, o cônjuge e os parentes, consanguíneos ou afins, até o segundo grau ou por adoção, do Presidente da República, de Governador de Estado ou Território, do Distrito Federal, de Prefeito [...].

48 "Comprovada a paternidade biológica após 40 anos do nascimento do filho e inexistindo interesse de anular ou retificar o atual registro de nascimento, cabível tão somente o reconhecimento da paternidade biológica, sem a concessão de direito hereditário ou retificação de nome. É que, se certa a paternidade biológica, o seu reconhecimento, sem a concessão dos demais direitos decorrentes do vínculo parental e inexistindo prejuízo e resistência de quem quer que seja, não viola o ordenamento jurídico. Ao contrário. Em casos como esse, negar 
(TJRJ, AI. 0008495-82.2010.8.19.0000) ${ }^{49}$, nos termos da Lei n. ${ }^{\circ} 11.924 / 09^{50}$ - ao som da poesia de Augusto dos Anjos ${ }^{51}$ - e da irrelevância de indagar quantos serão acrescidos - ou quantas vezes isso irá ocorrer - quando o direito é postulado de boa-fé e ainda de (b) direitos concedidos a alguns servidores públicos ${ }^{52}$ e (c) aos pensionistas ${ }^{53}$.

E, como um dos pontos de ancoragem desse direito está fixado na autoridade parental - a ser objetivamente aferida -, se ele é gestado em uma relação pública e duradoura - permeada pela socioafetividade - na qual nome e fama são meros reflexos

o reconhecimento da verdade biológica chega a ser uma forma de restrição dos direitos da personalidade do indivíduo [...]. Caso em que tão somente se reconhece a paternidade biológica, sem a concessão de qualquer outro efeito jurídico."

49 “A Lei n. ${ }^{\circ}$ 11.294/09 alterou o artigo 57 da Lei n. ${ }^{\circ} 6015$, acrescentando-lhe o $§ 8^{\circ}$, cuja regra permite ao enteado requerer a averbação em seu registro de patronímico do padrasto ou madrasta, sem prejuízo dos apelidos de família do requerente. A intenção do legislador não foi alijar o genitor biológico da vida de seu filho, mas franquear às famílias meios de demonstrar a posse de estado de filho que vivenciam. O prestígio ao vínculo afetivo não se confunde, porém, com permissivo à banalização de um dos mais relevantes elementos identificadores do ser humano, qual seja, o nome. A novel legislação, apesar de não fazer menção expressa ao consentimento do genitor, fala do cunho excepcional da alteração requerida, bem como exige a demonstração de "motivo ponderável" e assim o é justamente porque a modificação ora postulada não se encontra ao alvedrio das partes. Genitor que se encontra no pleno exercício do poder familiar, competindo-lhe, notadamente em razão da tenra idade da menor impúbere, dirigir-lhe a criação e educação, bem como representá-la."

50 Art. $2 . \mathrm{O}$ art. 57 da Lei n. ${ }^{\circ}$ 6.015/73 passa a vigorar acrescido do seguinte $§$ 8ㅇ: “Art. 57 [...] $§ 8$ 8o enteado ou a enteada, havendo motivo ponderável [...], poderá requerer ao juiz competente que, no registro de nascimento, seja averbado o nome de família de seu padrasto ou de sua madrasta, desde que haja expressa concordância destes, sem prejuízo de seus apelidos de família.”

51 A alusão diz respeito aos Versos íntimos, assim compostos:

Vês! Ninguém assistiu ao formidável

Enterro de tua última quimera.

Somente a Ingratidão - esta pantera -

Foi tua companheira inseparável!

Acostuma-te à lama que te espera!

o Homem, que, nesta terra miserável,

Mora, entre feras, sente inevitável

Necessidade de também ser fera.

Toma um fósforo. Acende teu cigarro!

$O$ beijo, amigo, é a véspera do escarro,

A mão que afaga é a mesma que apedreja.

Se a alguém causa inda pena a tua chaga,

Apedreja essa mão vil que te afaga,

Escarra nessa boca que te beija!

${ }^{52}$ Dentre outros, foram consagrados na Lei n. ${ }^{\circ} 8112 / 90$ os direitos à licença no caso de doença do padrasto ou madrasta e enteado (Art. 83), à ausência do serviço, sem perda de remuneração, em razão do falecimento da madrasta, do padrasto ou dos enteados (Art. 97), ao salário-família, considerando-se dependentes econômicos os enteados (Art. 197) e, a pensão por morte (Art. 217).

${ }^{53}$ Lei n. ${ }^{\circ}$ 8213/91. Art. 16. São beneficiários do Regime Geral de Previdência Social, na condição de dependentes do segurado: $[. ..] \S 2^{\circ}$.O enteado e o menor tutelado equiparam-se a filho mediante declaração do segurado e desde que comprovada a dependência econômica na forma estabelecida no Regulamento. 
(TEIXEIRA; RODRIGUES, 2009, p. 38-42), o que impede outros direitos? A inexistência de lei? Como um código que permite a um filho não querer ser filho ${ }^{54}$ pode impedi-lo quando a relação esteja amalgamada pala socioafetividade - de buscar o reconhecimento formal dos vínculos existentes para fazer reverberar, no sistema jurídico, a realidade vivida, ao mesmo tempo em que irá atribuir efetividade ao exercício de pretensões como a que está contida no direito aos alimentos (ANDRADE, 2010, p. 515-521) - sem a necessidade de malabarismos criativos e dignos de nota, como os que aludem ao parentesco por afinidade (TJMG, Ap. Cív. 1.0024.04.533394-51(1)/00) ${ }^{55}$ - alimentos pensados, aqui, tendo em conta a reciprocidade (ANDRADE, 2010, p. 517-518) e no direito à herança?

Infira-se, ademais, que é factível conceber que a aceitação pelo Direito do fenômeno da multiparentalidade promoverá a imposição e o delineamento - tão importante - de deveres como os de sustento e de cuidado, a cogestão no exercício das autoridades parentais (GIORGIS, 2009, p. 71), conformando, ainda, aspectos atados à guarda compartilhada (ou não) e ao exercício do dever de visitas (TJRS, Ap. Cív. $70018995241) .{ }^{56}$

Todos esses aspectos - e tantos outros desprezados por fatores como a aleatoriedade das fontes que informam esta pesquisa - devem ser considerados quando se busca compreender o delineamento de cada um dos papéis que exsurgem na complexidade de relações familiares que não cansam de se reinventar.

Talvez, esse seja o momento de aprender com os guaiaquis - indígenas estabelecidos no Paraguai -, tribo que imputa a paternidade a todos os maridos de uma mulher ao atribuir a cada um deles, consoante sua importância, poderes distintos. Talvez seja tempo de compreender com os wik monkans - tribo alocada no nordeste australiano - o significado de cada um dos diversos signos lá utilizados para significar as noções de pai biológico e socioafetivo (PARSEVAL, 1986, p. 35-36).

O que não se pode negar - mesmo em um tempo em que vozes respeitáveis ainda disseminam que a família é uma comunidade religiosa (DINIZ, 2011, p. 28) - é que,

${ }^{54}$ CC. Art. 1.614. O filho maior não pode ser reconhecido sem o seu consentimento, e o menor pode impugnar o reconhecimento, nos quatro anos que se seguirem à maioridade, ou à emancipação.

55 "Direito de família. Alimentos. Pedido feito pela enteada. Art. 1.595 do código civil. Existência de parentesco. Legitimidade passiva. O Código Civil atual considera que as pessoas ligadas por vínculo de afinidade são parentes entre si, o que se evidencia pelo uso da expressão "parentesco por afinidade", no parágrafo $1^{\circ}$. De seu artigo 1.595. O artigo 1.694, que trata da obrigação alimentar em virtude do parentesco, não distingue entre parentes consangüíneos e afins."

56 "Revelando o estudo social e psicológico que a menor, hoje com nove anos de idade, prefere a guarda do pai, com quem já se encontra desde o ajuizamento da ação, em 2004, internalizando o pai e a madrasta como casal parental, é de se manter a decisão, impondo-se, entretanto, preservar os vínculos com a mãe e irmãos (filhos desta) através [sic] de regulamentação de visitas." 
dentre as possibilidades atadas ao tema, está aquela que aduz a necessidade de levar o calor acolhedor do Direito "às relações vivencialmente constituídas" (FACHIN, 2011, p. $8)^{57}$, calor que permitirá encontrar as atribuições de cada um - alocadas entre a plenitude do ser e o vazio do nada - sem que para isso haja a necessidade de formatação de hierarquias a serem erigidas aprioristicamente (TEIXEIRA; RODRIGUES, 2009, p. 49).

E que não se levante - sem provas convincentes e argumentos válidos - que tudo isso provocará desvios e distúrbios na personalidade dos infantes e dos adolescentes que vivenciam cada uma dessas histórias. Antígona era neta da mãe e irmã do próprio pai e, nem por isso, mostrou qualquer maldade em seu coração. Ao contrário, esteve ao lado de Édipo enquanto esse vivia na escuridão e morreu defendendo o direito de o irmão ser sepultado.

\section{REFERÊNCIAS}

ALBUQUERQUE JÚNIOR, Roberto Paulino. A filiação socioafetiva no direito brasileiro e a impossibilidade de sua desconstituição posterior, Revista Brasileira de Direito de Família, Porto Alegre, v. 8, n. 39, p. 54-78, dez./jan. 2006-2007.

ANDRADE, Ronaldo Alves de. Reflexos jurídicos da filiação afetiva decorrentes do padrastio e do madrastio. In: CHINELLATO, Silmara Juny de Abreu et all (Org.). Direito de família no novo milênio: estudos em homenagem ao professor Álvaro Villaça Azevedo. São Paulo: Atlas, 2010.

ARIÈS, Philippe. História social da criança e da família. Trad. Dora Flaksman. 2. ed. Rio de Janeiro: LTC, 1981.

BAPTISTA DE MELLO, Joaquim. Direitos de bastardia: história, legislação, doutrina, jurisprudência e prática. São Paulo: Saraiva, 1933.

BARBOZA, Heloisa Helena. Efeitos jurídicos do parentesco socioafetivo, Revista Brasileira de Direito das Famílias e Sucessões, Porto Alegre, v. 11, n. 9, p. 25-34, abr./maio 2009.

BARROS, Fernanda Otoni de. Do direito ao pai. Belo Horizonte: Del Rey, 2001.

BITTAR, Eduardo. Família, sociedade e educação: um ensaio sobre individualismo, amor líquido e cultura pós-moderna, Revista Brasileira de Direito das Famílias e Sucessões, Porto Alegre, v. 9, n. 0, p. 7-25, out./nov. 2007.

BOEIRA. José Bernardo Ramos. Investigação de paternidade: posse de estado de filho, paternidade socioafetiva. Porto Alegre: LAEL, 1999.

BOSCARO, Márcio Antonio. Direito de filiação. São Paulo: RT, 2002.

BRITO, Leila Maria Torraca de. Paternidades contestadas: a definição da paternidade como um impasse contemporâneo. Belo Horizonte: Del Rey, 2008.

${ }^{57} \mathrm{O}$ que "faz com que seja protegido não um modelo abstrato de família, criado para conferir segurança e previsibilidade à acumulação patrimonial e à lógica proprietária, mas seja tutelado o indivíduo concreto, que poderá se desenvolver em sua plenitude intersubjetiva com o devido reconhecimento pelo Direito." 
CABRAL, Hildeliza Lacerda Tinoco Boechat. Afetividade como fundamento na parentalidade responsável, Revista Brasileira de Direito das Famílias e Sucessões, Porto Alegre, v. 13, n. 26, p. 47-72, fev./mar. 2012.

CÁRCOVA, Carlos María. Las teorias jurídicas post positivistas. 2. ed. Buenos Aires: Abeledo Perrot, 2009 .

COING, Helmut. Historia del derecho y dogmática jurídica, Revista Chilena de Derecho, Santiago, v. 9 , n. 2 , p. 245-257, maio/ago. 1982.

DERRIDA, Jacques. Aprender por fin a vivir: entrevista con Jean Birnbaum. Trad. Nicolás

Bersihand. Buenos Aires: Amorrortu, 2007.

DINIZ, Maria Helena. Curso de direito civil brasileiro: direito de família. 26. ed. São Paulo: Saraiva, 2011, v. 5.

ENGELS, Friedrich. A origem da família, da propriedade privada e do estado. Trad. José Silveira Paes. São Paulo: Global, 1984.

FACHIN, Luiz Edson. A filha das estrelas em busca do artigo perdido. In: PEREIRA, Rodrigo da Cunha (Coord.). Afeto, ética, família e o novo código civil. Belo Horizonte: Del Rey, 2004.

FACHIN, Luiz Edson. A refundação familiar: um aporte para o desenlace. In: MATOS, Ana Carla Harmatiuk (Org.). As famílias não fundadas no casamento e a condição feminina. Rio de Janeiro: Renovar, 2000.

FACHIN, Luiz Edson. Comentários ao novo código civil. Rio de Janeiro: Forense, 2003(a).

FACHIN, Luiz Edson. Da paternidade: relação biológica e afetiva. Belo Horizonte: Del Rey, 1996.

FACHIN, Luiz Edson. Direito de família: elementos críticos à luz do novo código civil brasileiro.

2. ed. Rio de Janeiro: Renovar, 2003(b).

FACHIN, Luiz Edson. Estabelecimento da filiação e paternidade presumida. Porto Alegre: SAFE, 1992.

FACHIN, Luiz Edson. Famílias: entre o público e o privado - problematizando espacialidades à luz da fenomenologia paralática, Revista Brasileira de Direito das Famílias e Sucessões, Porto Alegre, v. 13, n. 23, p. 5-14, ago./set. 2011.

FACHIN, Luiz Edson. Justiça e segurança jurídica - paradoxos e possibilidades da paternidade nas novas famílias. In: NICOLAU JÚNIOR, Mauro (Org.). Paternidade e coisa julgada: limites e possibilidades à luz dos direitos fundamentais e dos princípios constitucionais. Curitiba: Juruá, 2006.

FACHIN, Luiz Edson. Los derechos fundamentales en la construcción del derecho privado contemporáneo brasileño a partir del derecho civil-constitucional, Revista de Derecho Comparado, Santa Fe, n. 15, p. 243-272. 2009.

FALCKE, Denise. Mães e madrastas: quem são essas personagens? In: WAGNER, Adriana (Coord.). Família em cena: tramas, dramas e transformações. Petrópolis: Vozes, 2002.

FERREIRA, Arnaldo Amado. Determinação médico-legal da paternidade. São Paulo: Melhoramentos, 1939.

FERREIRA, Jussara Suzi Assis Borges Nasser; RÖRHMANN, Konstanze. As famílias pluriparentais ou mosaicos. In: PEREIRA, Rodrigo da Cunha (Org). Família e dignidade humana. São Paulo: IOB Thompson, 2006. 
FONTELES, Camila Santos Lima. Família e ciência: implicações da reprodução medicamente assistida nas novas configurações familiares. Dissertação (Mestrado) - Universidade de Fortaleza, Fortaleza, 1987.

FUSTEL DE COULANGES, Numa Denis. A cidade antiga: estudo sobre o culto, o direito e as instituições da Grécia e de Roma. Trad. Roberto Leal Ferreira. São Paulo: Martin Claret, 2009.

GAMA, Guilherme Calmon Nogueira da; GUERRA, Leandro dos Santos. A função social da família, Revista Brasileira de Direito de Família, Porto Alegre, v. 8, n. 39, p. 154-170, jan. 2007.

GILISSEN, John. Introdução histórica ao direito. Trad. Antonio Manuel Hespanha. Lisboa: Fundação Calouste Gulbenkian, 1988.

GIORGIS, Jose Carlos Teixeira. A paternidade fragmentada: família, sucessões, bioética. Porto Alegre: LAEL, 2007.

GIORGIS, José Carlos Teixeira. Arqueologia das famílias: da ginecocracia aos arranjos plurais, Revista Brasileira de Direito das Famílias e Sucessões, Porto Alegre, v. 12, n. 17, p. 41-73, ago./set. 2009.

GOMES, Orlando. Direito de família. 7. ed. Rio de Janeiro: Forense, 1994.

GOMES, Orlando. O novo direito de família. Porto Alegre: SAFE, 1984.

GROENINGA, Giselle Câmara. Afetos, sexualidade e violência - a família desmistificada. In: BASTOS, Eliene Ferreira; DIAS, Maria Berenice (Coord.). A família além dos mitos. Belo Horizonte: Del Rey, 2008.

GROENINGA, Giselle Câmara. Direito e psicanálise - um novo horizonte epistemológico. In: PEREIRA, Rodrigo da Cunha (Coord.). Afeto, ética, família e o novo código civil. Belo Horizonte: Del Rey, 2004.

GUIMARÃES, Laís Paulo Cotrim. A paternidade presumida no direito brasileiro e comparado. Rio de Janeiro: Renovar, 2001.

HERRERA, Florencia. La otra mamá: madres no biológicas en la pareja lésbica. In: GROSSI, Miriam; UZIEL, Anna Paula; MELLO, Luiz (Org.). Conjugalidades, parentalidades e identidades lésbicas, gays e travestis. Rio de Janeiro: Garamond, 2007.

HIRONAKA, Giselda Maria Fernandes Novaes. A incessante travessia dos tempos e a renovação dos paradigmas: a família, seu status e seu enquadramento na pós-modernidade. In: BASTOS, Eliene Ferreira; DIAS, Maria Berenice (Coords.). A família além dos mitos. Belo Horizonte: Del Rey, 2008.

KASER, Max. Direito privado romano. Trad. Samuel Rodrigues; Ferdinand Hämmerle. Lisboa: Fundação Calouste Gulbenkian, 1999.

LACAN, Jacques. Os complexos familiares na formação do indivíduo: ensaio de análise de uma função em psicologia. Trad. Marco Antonio Coutinho Jorge; Potiguara Mendes da Silveira Junior. 2. ed. Rio de Janeiro: Jorge Zahar, 2008.

LÔBO, Paulo Luiz Netto. A repersonalização das relações de família, Revista Brasileira de Direito de Família, Porto Alegre, v. 6, n. 24, p. 136-156, jun./jul. 2004.

LÔBO, Paulo Luiz Netto. Socioafetividade no direito de família: a persistente trajetória de um conceito fundamental, Revista Brasileira de Direito de Família, Porto Alegre, v. 10, n. 5, p. 5-22, ago./set. 2008. 
LÔBO, Paulo Luiz Netto. Direito civil: famílias. 3. ed. São Paulo: Saraiva, 2010.

MADALENO, Rolf. Novas perspectivas no direito de família. Porto Alegre: LAEL, 2000.

MEDEIROS, Olga Helena Silva de. Genealogia do direito privado na antropologia da família líquida. Dissertação (Mestrado) - Pontifícia Universidade Católica do Rio Grande do Sul, Porto Alegre, 2008.

MEIRELLES, Jussara. Gestação por outrem e determinação da maternidade: mãe de aluguel. Curitiba: Gênesis, 1998.

MOREIRA, Fernanda de Souza. O direito a alimentos do nascido do banco de sêmen e a legitimação passiva do doador na inseminação artificial heteróloga: uma colisão de direitos fundamentais, Revista Brasileira de Direito das Famílias e Sucessões, Porto Alegre, v. 12, n. 15, p. 30-49, abr./maio 2010.

NIETZSCHE, Friedrich Wilhelm. Ecce homo: de como a gente se torna o que a gente é. Trad. Marcelo Backes. Porto Alegre: L\&PM, 2009.

NIETZSCHE, Friedrich Wilhelm. O anticristo: maldição contra o cristianismo. Trad. Renato Zwick. Porto Alegre: L\&PM, 2012.

NOGUEIRA, Jacqueline Filgueras. A filiação que se constrói: o reconhecimento do afeto como valor jurídico. São Paulo: Memória Jurídica, 2001.

PARSEVAL, Geneviève Delaise de. A parte do pai. Trad. Lígia Watanabe e Theresa Stummer. Porto Alegre: L\&PM, 1986.

PAULO, Beatrice Marinho. Ser mãe nas novas configurações familiares: a maternidade psicoafetiva, Revista Brasileira de Direito das Famílias e Sucessões, Porto Alegre, v. 11, n. 9, p. 35-58, abr./maio 2009(a).

PAULO, Beatrice Marinho. Ser pai nas novas configurações familiares: a paternidade psicoafetiva, Revista Brasileira de Direito das Famílias e Sucessões, Porto Alegre, v. 11, n. 10, p. 5-33, jun./jul. 2009(b).

PEREIRA, Rodrigo da Cunha. Direito de família: uma abordagem psicanalítica. 3. ed. Belo Horizonte: Del Rey, 2003.

PEREIRA, Tânia da Silva. O "cuidado" chega ao STJ, Revista Brasileira de Direito das Famílias e Sucessões, Porto Alegre, v. 12, n. 19, p. 100-121, dez./jan. 2010-2011.

PEREIRA, Virgilio de Sá. Direito de família. 3. ed. São Paulo: Método, 2008.

RUZYK, Carlos Eduardo Pianovski. Famílias simultâneas: da unidade codificada à pluralidade constitucional. Rio de Janeiro: Renovar, 2005.

SACCO, Rodolfo. Codificare: modo superato di legiferare?, Rivista di Diritto Civile, Padova, anno 29, n. 2, p. 117-135, mar./abr. 1983.

TEIXEIRA, Ana Carolina Brochado; RODRIGUES, Renata de Lima. Multiparentalidade como fenômeno jurídico contemporâneo, Revista Brasileira de Direito das Famílias e Sucessões, Porto Alegre, v. 11, n. 14, p. 89-106, fev./mar. 2010.

TEIXEIRA, Ana Carolina Brochado; RODRIGUES, Renata de Lima. Multiparentalidade como efeito da socioafetividade nas famílias recompostas, Revista Brasileira de Direito das Famílias e Sucessões, Porto Alegre, v. 11, n. 10, p. 34-60, jun./jul. 2009. 
VALADARES, Maria Goreth Macedo. As famílias reconstituídas. In: TEIXEIRA, Ana Carolina Brochado; RIBEIRO, Gustavo Pereira Leite (Coord.). Manual de direito das famílias e das sucessões. Belo Horizonte: Del Rey, 2008.

VERUCCI, Florisa. O direito de ter pai. In: LEITE, Eduardo de Oliveira (Coord.). Grandes temas da atualidade: DNA como meio de prova da filiação. Rio de Janeiro: Forense, 2000.

WAGNER, Adriana. Possibilidades e potencialidades da família: a construção de novos arranjos a partir do recasamento. In: WAGNER, Adriana (Coord.). Família em cena: tramas, dramas e transformações. Petrópolis: Vozes, 2002.

WELTER, Belmiro Pedro. Teoria tridimensional no direito de família: reconhecimento de todos os direitos das filiações genética e socioafetiva, Revista Brasileira de Direito de Família, Porto Alegre, v. 10, n. 8, p. 104-123, fev./mar. 2009. 